\title{
Neurosurgery for Refractory Schizophrenia: A Systematic Literature Review
}

\section{Neurocirurgia para esquizofrenia refratária: Uma revisão sistemática da literatura}

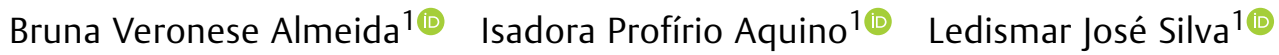 \\ ${ }^{1}$ Departament of Medicine, Escola de Ciências Médicas, \\ Farmacêuticas e Biomédicas, Pontifícia Universidade Católica de \\ Goiás, Goiânia, Goiás, Brazil \\ Arq Bras Neurocir 2020;39(2):108-115.

\begin{abstract}
Address for correspondence Ledismar José da Silva, MSc, Departamento de Medicina, Escola de Ciências Médicas, Farmacêuticas e Biomédicas, Pontifícia Universidade Católica de Goiás (PUC-Goiás), Avenida Universitária 1.440, Setor Universitário,
\end{abstract} \\ 74605-010, Goiânia, Goiás, Brasil (e-mail: ledismarsilva@gmail.com).
}

\section{Abstract \\ Keywords \\ - schizophrenia \\ - psychosurgery \\ - ablation techniques \\ - deep brain stimulation \\ - neurosurgery}

Resumo
Schizophrenia is a chronic and disabling psychiatric disease that can be refractory to conventional treatment. The present study aims to gather information about the circuitry related to schizophrenia to describe possible surgical targets, and to establish whether psychosurgery can be a safe and effective treatment option for refractory schizophrenia. A systematic review of the literature was conducted and reported according to the Preferred Reporting Items for Systematic Reviews and Meta-Analyses (PRISMA) statement. An electronic search was performed in the Pubmed and BVSalud databases using medical subject headings (MeSH) combined with Boolean operators. Out of the 724 studies retrieved, 13 were included in the review. Regarding leucotomy without a stereotactic approach, we found side effects such as irritability, nervous excitement, cases of disinhibition, and compromised normal social control. In other stereotactic procedures, there was some improvement, mainly regarding aggressiveness and positive symptoms; an anterior capsulotomy had an efficacy rate of $74 \%$ according to the Clinical Global Impression (CGI) rating scales. The only deep brain stimulation (DBS) case report found in our study described a significant improvement in the positive and negative symptoms. The use of a stereotactic approach enables psychosurgery to be a safe and effective treatment option in cases of refractory schizophrenia, improving the quality of life and the symptoms. Cognitive and negative symptoms remain a challenge in the treatment of schizophrenia, revealing that more targets in the circuitry must be surgically explored. Furthermore, more clinical trials are needed to compare these many surgical techniques and targets, using a standard evaluation parameter. The results show that DBS has a promising future in the treatment of refractory schizophrenia.

A esquizofrenia é uma doença psiquiátrica crônica e incapacitante, que pode ser refratária ao tratamento convencional Este estudo tem como objetivo coletar informações sobre a circuitaria relacionada à esquizofrenia, descrever possíveis alvos cirúrgicos, e estabelecer se a psicocirurgia pode ser uma opção de tratamento segura received

June 10, 2019

accepted

December 11, 2019
DOI https://doi.org/

10.1055/s-0040-1702978. ISSN 0103-5355.
Copyright (e 2020 by Thieme Revinter

Publicações Ltda, Rio de Janeiro, Brazil
License terms

(c) $(1) \$$ 
e eficaz para a esquizofrenia refratária. Uma revisão sistemática da literatura foi realizada de acordo com a recomendação Itens Preferidos para Relatar Revisões Sistemáticas e Meta-análises (Preferred Reporting Items for Systematic Reviews and Meta-Analyses, PRISMA, em inglês). Uma busca eletrônica foi realizada nas bases de dados Pubmed e BVSalud, e, de 724 estudos coletados, 13 foram incluídos na revisão. Com relação à leucotomia sem abordagem estereotáxica, foram encontrados efeitos colaterais como irritabilidade, excitação nervosa, e casos de desinibição e comprometimento do controle social normal. Em outros procedimentos estereotáxicos, houve alguma melhora, principalmente na agressividade e nos sintomas positivos. A capsulotomia anterior apresentou taxa de eficácia de $74 \%$ de acordo com as escalas de Impressão Clínica Global (Clinical Global Impression, CGI, em inglês). No único relato de

\section{Palavras-chave}

- esquizofrenia

- psicocirurgia

- técnicas de ablação

- estimulação encefálica profunda

- neurocirurgia caso de estimulação cerebral profunda (ECP) encontrado em nosso estudo os autores descreveram uma melhora significativa nos sintomas positivos e negativos. $\mathrm{O}$ uso da abordagem estereotáxica permite que a psicocirurgia seja uma opção de tratamento segura e eficaz para a esquizofrenia refratária. Os sintomas cognitivos e negativos permanecem um desafio no tratamento da esquizofrenia, revelando que mais alvos devem ser explorados cirurgicamente. Além disso, mais ensaios clínicos são necessários para comparar essas várias técnicas e alvos cirúrgicos, segundo parâmetro comum de avaliação. Os resultados mostram que a ECP tem um futuro promissor no tratamento da esquizofrenia refratária.

\section{Introduction}

Schizophrenia is a chronic and disabling psychiatric disorder that leads to a considerable reduction in quality of life. ${ }^{1}$ It is estimated to reach $1 \%$ of the world's population, ${ }^{2}$ and only $10 \%$ to $20 \%$ of schizophrenics are able to get a competitive job, leading to hardships in terms of self-sufficiency. ${ }^{3}$ In addition, it is among the costliest medical conditions to have in the world. ${ }^{4}$

The symptoms of schizophrenia are divided into three components: positive symptoms, which include hallucinations, confused thoughts, and abnormal or grossly disorganized motor behavior; negative symptoms, which are characterized by diminished emotional expression, alogia, dysfunction in socialization, avolition, and anhedonia; and cognitive impairments, which are expressed by attention deficit, impairment in working memory, and executive dysfunction.,

The pharmacological treatment with antipsychotics is the treatment of choice in cases of schizophrenia. The typical antipsychotics, such as chlorpromazine and haloperidol, act by blocking dopamine D2 receptors. ${ }^{2,7}$ About $10 \%$ to $30 \%$ of the patients are refractory to these drugs, and clozapine, an atypical antipsychotic that also acts on serotonergic receptors, should be used in these cases. ${ }^{7,8}$ However, the clinical symptoms persist in $\sim 40 \%$ to $70 \%$ of the patients, resulting in super-refractory schizophrenia. It is in this context that neurosurgery for psychiatric disorders is gaining pace as a therapeutic option. ${ }^{9}$

Considering the impact of schizophrenia on the world population, as well as the technological advances in the field of psychosurgery, the present literature review aims to gather information about the circuitry related to schizophrenia, to describe possible surgical targets, and to establish whether psychosurgery can be a safe and effective treatment option for refractory schizophrenia.

\section{Methods}

\section{Literature Search}

The present manuscript was written according to the Preferred Reporting Items for Systematic Reviews and Meta-Analyses (PRISMA) statement.

An electronic search was conducted in the BVSalud and PubMed databases in October 2018. The search was performed using medical subject headings (MeSH) combined with Boolean operators. The following terms were searched: schizophrenia AND ablation, schizophrenia AND deep brain stimulation, schizophrenia AND neurosurgery, schizophrenia AND neurosurgery AND history, and schizophrenia AND psychosurgery.

We only retrieved articles with the full text available, studies written in English, Spanish, or Portuguese, and studies in humans of all ages and both sexes. All articles published before October 2018 were retrieved.

\section{Study Selection}

The inclusion criteria were articles with the full text available, randomized clinical trials, observational studies, and case reports about neurosurgery in patients with refractory schizophrenia. The studies were excluded if they: involved non-invasive procedures, did not apply to the key question, did not address the relevant outcome, did not have a clear description of the methods, were review articles, abstracts, editorials, comments, or studies unrelated to the surgical procedures performed in humans. 
110 Neurosurgery for Refractory Schizophrenia Almeida et al.

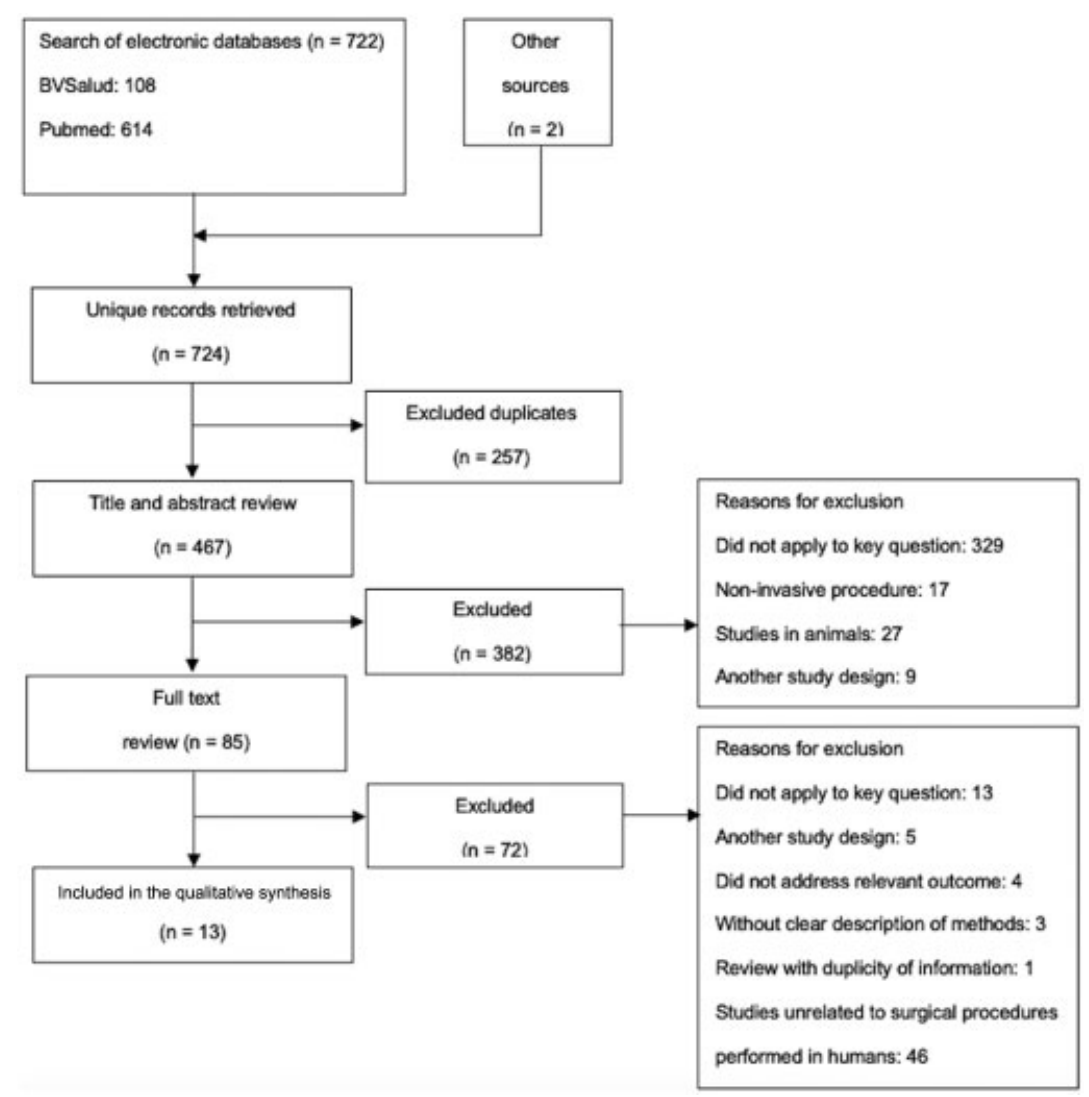

Fig. 1 Flowchart of the literature review.

Duplicated studies were excluded using the Zotero (Andrew W. Mellon Foundation, Institute of Museum and Library Services, Alfred P. Sloan Foundation, VA, US) software, version 5.0.66. Titles and abstracts were reviewed independently by two authors (B.V.A and I.P.A) in a first screening according to the aforementioned criteria. All eligible articles were retrieved, and the final selection was made after the full texts of the articles were read. The synthesis of the selection process and the selected articles are in - Figure 1 and - Table 1 respectively.

\section{Data Extraction}

The data extracted from the selected articles were study design (randomized controlled trial, cohort, or case report),

Table 1 Characteristics of the studies included in the review according to author, year of publication, location, study design, and sample

\begin{tabular}{|l|l|l|l|}
\hline Author, year of publication & Location & Study design & $\begin{array}{l}\text { Total sample (number of } \\
\text { schizophrenic patients) }\end{array}$ \\
\hline Benson et al, $1981^{15}$ & Boston, USA & Retrospective cohort & $26(16)$ \\
\hline Kelly et al, $1972^{16}$ & London, England & Prospective cohort & $78(6)$ \\
\hline Mckenzie and Kaczanowski, $1964^{17}$ & Toronto, Canada & Randomized controlled trial & $183(150)$ \\
\hline Hirose, $1965^{18}$ & Tokyo, Japan & Prospective cohort & $77(29)$ \\
\hline Ström-Olsen and Carlisle, $1971^{19}$ & London, England & Retrospective cohort & $210(5)$ \\
\hline Göktepe et al, $1975^{20}$ & London, England & Retrospective cohort & $208(4)$ \\
\hline Kelly et al, $1973^{21}$ & London, England & Prospective cohort & $40(6)$ \\
\hline Mitchell-Heggs et al, $1976^{22}$ & London, England & Prospective cohort & $66(7)$ \\
\hline Parhad, $1953^{23}$ & Baghdad, Iraq & Prospective cohort & $28(18)$ \\
\hline Ballantine et al, $1987^{24}$ & Boston, USA & Retrospective cohort & $198(11)$ \\
\hline Liu et al, $2014^{4}$ & Shanghai, China & Prospective cohort & 116 patients with schizophrenia \\
\hline Schvarcz et al, $1972^{13}$ & Buenos Aires, Argentina & Case series & $11(1)$ \\
\hline Corripio et al, $2016^{25}$ & Barcelona, Spain & Case report & 1 patient with schizophrenia \\
\hline
\end{tabular}


study sample (number of patients with schizophrenia), maximum follow-up, complications, and relevant outcome.

\section{Circuitry}

Four hypotheses are described in the literature to elucidate the circuitry of schizophrenia, and, consequently, to indicate the possible surgical targets: the dopaminergic, GABAergic, glutamatergic, and serotoninergic theories. ${ }^{1,2,4}$

The dopaminergic hypothesis is the most accepted theory, but it is often considered a simplification of the circuitry of schizophrenia, given the poor efficacy of the dopamine D2 receptor antagonist drugs. ${ }^{1}$ In this theory, positive symptoms are related to hyperactivity in the mesolimbic dopaminergic system, leading to a hyperdopaminergic state. In this system, the ventral tegmental area (VTA) makes connections with the nucleus accumbens (NAcc), the septal nuclei, and the amygdala via the medial prosencephalic bundle, and with the prefrontal cortex (PFC) via the cingulate gyrus. ${ }^{1-3,10,11}$

It is proposed that in psychosis the deregulation of the release of dopamine initially results in an incorrect reward stimulus that would be ignored in another situation, leading to an aberrant overhang in the upper cortical levels, and this would translate clinically as positive symptoms. ${ }^{11}$

Activation of the hippocampus leads to the release of dopamine in the mesolimbic pathway. Studies have shown that its hyperactivation would be the cause of the hyperdopaminergic state, since its activation stimulates GABAergic neurons in the NAcc, which, in turn, inhibits the GABAergic neurons of the globus pallidus (GP), which are responsible for the inhibition of the dopaminergic neurons in the VTA. ${ }^{3,11-13}$ In contrast, a hypodopaminergic state in the mesocortical circuit, linking the VTA to the PFC, would be related to negative symptoms. ${ }^{1,2}$

According to the GABAergic and glutamatergic hypotheses, an imbalance in the dopaminergic pathways is related to changes in regulation caused by gamma-aminobutyric acid (GABA) and glutamate. In the glutamatergic system, glutamate signaling via the $\mathrm{N}$-methyl D-aspartate (NMDA) receptor would be hypofunctioning. ${ }^{2}$ In the GABAergic system, the positive symptoms would be related to a decreased inhibition by GABA-a receptors, and the negative symptoms would be associated with GABA-b receptors. ${ }^{11}$ In addition, studies have confirmed the influence of GABA on the neuronal oscillations in the brain areas related to the cognitive domain. ${ }^{2}$

In the serotoninergic theory, serotonin, which is released by the medial and dorsal raphe neurons, inhibits the activity of dopaminergic neurons in this region when acting on 5HT2A receptors in the PFC, which also leads to a hypodopaminergic state. ${ }^{4}$

In addition to the proposed targets in these theories, the posterior hypothalamic zone, which includes the posterior nucleus, the tuberomammillary nuclei, and the mammillary bodies, is related to aggressive and defensive behavior, which is often present in patients with schizophrenia. Furthermore, the mammillary bodies are part of the Papez circuit, which is closely associated with the coding of the episodic memory. Therefore, the hypothalamus represents an important target in the surgical approach. ${ }^{14}$

\section{Results}

Out of the 724 studies retrieved, 13 were included in the review and synthetized in - Table 2.

Benson et al $^{15}$ evaluated the long-term effects in 16 patients with refractory schizophrenia who underwent a prefrontal leucotomy 25 years prior to the study. As a result, many patients remained psychotic, with hallucinations and delusions, and severe apathy was the most observed result. Irritability, nervous excitement, and some cases of disinhibition and impairment of normal social control were also documented.

In another study conducted by Kelly et al, ${ }^{16}$ involving patients with mental disorders submitted to an orbitofrontal leucotomy, 6 of the patients were schizophrenic, and the authors demonstrated a 50\% improvement rate, mainly in depression and anxiety, which was not considered significant.

A similar finding was made by Mackenzie and Kaczanowski, ${ }^{17}$ who demonstrated no significant difference between the results when comparing leucotomized and non-leucotomized patients.

Hirose $^{18}$ reported that, in a group of 18 schizophrenics who underwent a leucotomy, only 4 were discharged. The results were similar to those obtained with antipsychotics. In total, 14 patients remained hospitalized, but as they became more docile, calm, and cooperative, many of them improved their ability to work.

Ström-Olsen and Carlisle ${ }^{19}$ analyzed the performance of a stereotaxic bi-frontal tractotomy in 5 schizophrenic patients with bizarre behavior or paranoid delusions with hallucinations and impulsive behavior, associated with autism, emotional blunting, the incongruity of affect, and associative thinking disorder. Of these patients, 3 remained unchanged, and 2 showed a decrease in tension, aggression, and depression. However, there were no cases of recovery with only mild symptoms.

In a study conducted by Göktepe et al, ${ }^{20} 208$ patients with psychiatric disorders (among them 4 schizophrenics) were submitted to a stereotactic subcaudate tractotomy. As a result, two patients showed improvements, but significant symptoms remained, interfering with the patients' life. The two other schizophrenic patients remained unchanged.

Kelly et $\mathrm{al}^{21}$ evaluated 40 psychiatric patients ( 6 of them with refractory schizophrenia) who underwent a stereotactic limbic leucotomy from 1970 to 1972 . The total improvement index found in the 6 postoperative weeks was of $66 \%$, and 4 out of the 6 schizophrenic patients had positive results, mainly in relation to anxiety and the obsessive thoughts associated with delusions.

Positive results related to a stereotactic limbic leucotomy were also found by Mitchell-Heggs et $\mathrm{al}^{22}$ in a study of 7 patients with refractory schizophrenia, in which an improvement of $86 \%$ was observed when the patients were evaluated about 16 months after the procedure. In total, 4 patients showed great clinical improvement, 2 showed a slight improvement, and 1 remained unchanged.

Choosing a bilateral cingulo-tractotomy as the approach, Parhad $^{23}$ divided a group of 18 schizophrenics into 2 subgroups: subgroup A was composed of 5 patients with recent 
112 Neurosurgery for Refractory Schizophrenia Almeida et al.

Table 2 Summary of study results according to the procedure

\begin{tabular}{|c|c|c|c|c|c|}
\hline Procedure & Author, year & $\begin{array}{l}\text { Number of } \\
\text { patients with } \\
\text { schizophrenia }\end{array}$ & $\begin{array}{l}\text { Maximum } \\
\text { follow-up }\end{array}$ & Outcomes & Complications \\
\hline \multirow[t]{3}{*}{ Leucotomy } & $\begin{array}{l}\text { Benson et al, } \\
1981^{15}\end{array}$ & 16 & 25 years & $\begin{array}{l}\text { Many of the patients remained } \\
\text { severely psychotic, with hallucinations } \\
\text { and delusions. In total, } 5 \text { patients had a } \\
\text { good performance in the neuropsy- } \\
\text { chological testing when compared to } \\
\text { the control group. }\end{array}$ & $\begin{array}{l}50 \% \text { of leucotomized patients with } \\
\text { a history of seizures; epileptogenic } \\
\text { activity was identified in the } \\
\text { electroencephalogram of } 2 \\
\text { patients. }\end{array}$ \\
\hline & $\begin{array}{l}\text { Kelly et al, } \\
1972^{16}\end{array}$ & 6 & 18 months & $\begin{array}{l}3 \text { patients improved, } 3 \text { did not } \\
\text { improve. }\end{array}$ & $\begin{array}{l}\text { Increased outspokenness and mild } \\
\text { euphoria, aggressiveness, and } \\
\text { weight gain, no seizures. }\end{array}$ \\
\hline & $\begin{array}{l}\text { Mckenzie and } \\
\text { Kaczanowski, } \\
1964^{17}\end{array}$ & 150 & 5 years & $\begin{array}{l}57 \text { patients were discharged from the } \\
\text { clinic, no significant difference was } \\
\text { found between the patients submitted } \\
\text { to surgery and the controls. }\end{array}$ & Not mentioned \\
\hline $\begin{array}{l}\text { Orbito- } \\
\text { ventromedial } \\
\text { undercutting }\end{array}$ & Hirose, $1965^{18}$ & 29 & 6.5 years & $\begin{array}{l}3 \text { patients improved markedly, } \\
16 \text { improved moderately, and } \\
5 \text { improved slightly. }\end{array}$ & $\begin{array}{l}\text { Postoperative convulsions } \\
\text { ( } 3 \text { cases). }\end{array}$ \\
\hline \multirow[t]{2}{*}{$\begin{array}{l}\text { Subcaudate } \\
\text { tractotomy }\end{array}$} & $\begin{array}{l}\text { Ström-Olsen and } \\
\text { Carlisle, } 1971^{19}\end{array}$ & 5 & 7 years & $\begin{array}{l}2 \text { patients improved (decrease in } \\
\text { tension, aggression, and depression), } \\
\text { but still needed treatment; } 3 \text { patients } \\
\text { remained unchanged; no patient } \\
\text { recovered completely. }\end{array}$ & $\begin{array}{l}\text { A male schizophrenic on chlor- } \\
\text { promazine had one fit eighteen } \\
\text { months after the surgery. No gross } \\
\text { personality or behavioral changes } \\
\text { were noted. }\end{array}$ \\
\hline & $\begin{array}{l}\text { Göktepe et al, } \\
1975^{20}\end{array}$ & 4 & 4.5 years & $\begin{array}{l}2 \text { patients improved, but significant } \\
\text { symptoms remained; } 2 \text { patients } \\
\text { remained unchanged. }\end{array}$ & $\begin{array}{l}\text { Epilepsy, excessive eating, } \\
\text { volubility, extravagance, reduction } \\
\text { of social standards, and decrease in } \\
\text { empathy. }\end{array}$ \\
\hline \multirow[t]{3}{*}{$\begin{array}{l}\text { Limbic } \\
\text { leucotomy }\end{array}$} & $\begin{array}{l}\text { Kelly et al, } \\
1973^{21}\end{array}$ & 6 & 6 weeks & $\begin{array}{l}1 \text { patient was symptom free, } \\
3 \text { improved, and } 2 \text { remained } \\
\text { unchanged. }\end{array}$ & $\begin{array}{l}\text { Postoperative short period of } \\
\text { confusion, lethargy, and sphincter } \\
\text { disturbances. }\end{array}$ \\
\hline & $\begin{array}{l}\text { Mitchell-Heggs } \\
\text { et al, } 1976^{22}\end{array}$ & 7 & 16 months & $\begin{array}{l}4 \text { patients showed great improvement, } \\
\text { and } 2 \text { showed a slight improvement } \\
\text { (decrease in anxiety, depression, and in } \\
\text { the intensity and number of psychotic } \\
\text { episodes), and } 1 \text { remained unchanged. }\end{array}$ & $\begin{array}{l}\text { No seizures, no weight gain, and } \\
\text { light effects on personality. }\end{array}$ \\
\hline & Parhad, $1953^{23}$ & 18 & Not specified & $\begin{array}{l}14 \text { patients improved ( } 6 \text { had a } \\
\text { complete recovery and } 2 \text { relapsed), } \\
\text { and } 4 \text { remained unchanged. }\end{array}$ & $\begin{array}{l}1 \text { death (self-induced infection), } \\
\text { postoperative vomiting, and } \\
\text { wetting. No seizures. }\end{array}$ \\
\hline Cingulotomy & $\begin{array}{l}\text { Ballantine et al, } \\
1987^{24}\end{array}$ & 11 & 22 years & $\begin{array}{l}3 \text { patients had a negligible improve- } \\
\text { ment or showed no remission, } 4 \text { had a } \\
\text { considerable improvement, and } \\
4 \text { became less violent. }\end{array}$ & Suicide. \\
\hline $\begin{array}{l}\text { Anterior } \\
\text { capsulotomy }\end{array}$ & Liu et al, $2014^{4}$ & 116 & 24 months & $\begin{array}{l}\text { The positive and negative symptoms } \\
\text { improved. Best improvement: aggres- } \\
\text { sive behavior ( } 78 \text { improved, } 16 \text { did } \\
\text { not); suicidal tendencies }(n=15) \text { or } \\
\text { self-destructive behavior }(n=3) \\
\text { disappeared completely; there were } \\
8 \text { relapses. }\end{array}$ & $\begin{array}{l}\text { Short-term complications: urinary } \\
\text { incontinence }(n=18) \text {, disorienta- } \\
\text { tion }(n=4) \text {, sleep disorder }(n=12) \text {, } \\
\text { and fatigue }(n=10) \text {. Long-term } \\
\text { complications: bulimia ( }(n=9) \text {, } \\
\text { memory loss }(n=7) \text {, personality } \\
\text { changes }(n=6) \text {, lazy behavior } \\
(n=5) \text {, and hypererotism }(n=4) \text {. } \\
\text { There were also cases of intracranial } \\
\text { hemorrhages }(1 \%) \text { and infections } \\
(1 \%) \text {, but no seizures. }\end{array}$ \\
\hline Hypothalotomy & $\begin{array}{l}\text { Schvarcz et al, } \\
1972^{13}\end{array}$ & 1 & 48 months & $\begin{array}{l}\text { Decrease in aggressive behavior; the } \\
\text { patient was discharged home. }\end{array}$ & No complications. \\
\hline $\begin{array}{l}\text { Deep brain } \\
\text { stimulation } \\
\text { in the nucleus } \\
\text { accumbens }\end{array}$ & $\begin{array}{l}\text { Corripio et al, } \\
2016^{25}\end{array}$ & 1 & 11 months & $\begin{array}{l}\text { A significantly lower level of positive } \\
\text { symptoms (the PANSS positive factor } \\
\text { ranged from from } 13 \text { before the } \\
\text { implantation to } 5 \text { at } 44 \text { weeks } \\
\text { (reduction of } 61.54 \% \text { ), and a substan- } \\
\text { tial reduction in the negative symp- } \\
\text { toms (the PANSS negative factor } \\
\text { ranged from } 18 \text { to } 12 \text { (reduction of } \\
33.4 \% \text { ). }\end{array}$ & Akathisia. \\
\hline
\end{tabular}

Abbreviation: PANSS, Positive and Negative Syndrome Scale. 
untreated schizophrenia, and subgroup B was composed of 13 patients with chronic refractory schizophrenia. In subgroup A, all of the patients were discharged to their homes within two weeks, and returned to work within a month. In subgroup B, three patients returned to work after one month, but, four months later, two of them relapsed; five improved after the operation, becoming less aggressive and more manageable: they did not return to work, but some began to do household chores. The remaining 4 patients did not benefit from the operation.

Ballantine et $\mathrm{al}^{24}$ conducted a study involving the cingulate gyrus. Stereotactic cingulotomy was performed in 11 patients diagnosed with refractory schizophrenia, and 3 of them had insignificant results, four showed an improvement, and four others who were violent and selfmutilating had a significant improvement of these symptoms.

In a study of the anterior capsule as a target, Liu et $\mathrm{al}^{4}$ followed up on 116 patients with refractory schizophrenia who underwent a bilateral anterior capsulotomy with stereotaxis. The evaluations were performed 3 weeks and 24 months after surgery, but 16 of the patients did not complete the follow-up. There was a $74 \%$ efficacy rate according to the Clinical Global Impression (CGI) rating scales, and there was an apparent improvement according to the statistical analysis for the positive and negative symptom scale (PANSS). This procedure showed a significant improvement in aggressiveness, hallucinations, and delirium.

An approach with the hypothalamus as a target was performed in a study published in 1972 by Schvarcz et $\mathrm{al}^{13}$ who described stereotactically-guided hypothalamic lesions in a 32-year-old patient with aggressive schizophrenia. His behavior led to his solitary confinement for 12 years in a psychiatric institution. In the immediate postoperative period, the patient remained calm and manageable. Five days after the procedure, he was able to resume social interactions with the other inpatients. Two weeks later, he was readmitted for contralateral hypothalamotomy, and two months later he was discharged, returning to his family without any aggressive attacks. There was no postoperative intelligence deficit.

The target site chosen in this procedure was the medial part of the posterior hypothalamic area, in a region $3 \mathrm{~mm}$ perpendicularly below the midpoint of the intercommissural line, and $2 \mathrm{~mm}$ from the lateral wall of the third ventricle.

Recently, in a case report, Corripio et $\mathrm{al}^{25}$ described the case of a 46-year-old refractory schizophrenic woman who underwent bilateral electrode implantation in the Nacc. When bilateral stimulation was performed, she experienced akathisia, which disappeared when the unilateral stimulation was reestablished. After a maximum follow-up of 11 months and approximately 6 months of clinical stability, she had an important reduction in the positive symptoms, with a $61.54 \%$ decrease in the PANSS positive factor and a significant reduction in the negative symptoms, with a $33.4 \%$ decrease in the PANSS negative factor.

\section{Discussion}

Psychosurgery has a controversial history that began with neurologist Egas Moniz, the creator of the surgical procedure known as lobotomy in 1935, and with Water Freeman and James Watts, who gave continuity to the procedure by changing its methods. Despite the reasonable improvement in some of the symptoms of schizophrenia and even good results, society came to know lobotomized patients with numerous complications, including epileptic seizures and 'frontal lobe syndrome.'1,26-45 With the advent of the first antipsychotic drug, psychosurgery fell into disuse, and was remembered for the atrocities of its idealizers. The connections of the prefrontal region were, nevertheless, better elucidated. ${ }^{1,26,46,47}$

We observed that in the studies regarding pre-frontal leucotomy ${ }^{15-17}$, there were no significant results or changes in personality that really affected the quality of life, which contributed to the refusal to have this procedure performed; however, it was noted that more recent publications ${ }^{21-23}$ described more effective and beneficial results.

Better results with fewer side effects were possible thanks to the advances in imaging techniques and the rise of the stereotactic surgery. The surgery has enabled the location of the targets with high precision and minimal tissue damage, 4,14,48 which is noticeable when establishing a temporal line in the results presented, dividing the conventional leucotomies, as in the study by Benson et $\mathrm{al}^{15}$ of the procedures using a stereotactic technique.

In addition to treat destructive lesions, electrodes can be deployed in certain brain areas in order to generate electrical impulses, a procedure called Deep Brain Stimulation (DBS). ${ }^{12,27}$ In DBS, electrical stimulation occurs when low a frequency is used, and electrical inhibition is used when a high frequency is used. Currently, another technique has been designed to improve the accuracy of DBS, called closedloop deep brain stimulation (CL-DBS), which uses studies of the complete connection that occurs from one point to another point in the brain through neural pathways, called a connectome. $^{49-51}$

One of the advantages of DBS, when compared to other surgical procedures, is its reversibility. ${ }^{12}$ Studies have also reported its benefit in reducing recurrence rates, decreasing the intensity of residual psychosis, and improving cognitive impairment by reducing the negative symptoms. ${ }^{3}$ Results from the Corripio et $\mathrm{al}^{25}$ case report revealed the great potential of this procedure, with a significant improvement in symptoms and only one side effect, which was reversible. ${ }^{25}$ However, one disadvantage is the fact that it is still an invasive procedure that has the risk of causing edema, hemorrhages, and seizures. ${ }^{12}$

Deep brain stimulation is performed with high-cost electrodes in various brain regions, which reduces its applicability on a large scale. In addition, the need for maintenance further increases the cost of the procedure. We believe that this low financial accessibility is one of the reasons why ablative surgeries, although irreversible, have become more preferred than DBS. These might be one of the more probable 
reasons for not identifying many performed DBS studies related to schizophrenia in our search.

Regarding ablative procedures, bilateral anterior cingulotomy as a replacement for lobotomy has been long questioned, but current improvement in the patients' quality of life and cognition are already confirmed. ${ }^{24,52}$ However, when comparing its efficacy for schizophrenia in relation to other psychiatric disorders, it is noted that it is still low. ${ }^{53}$ In our results, a bilateral cingulo-tractotomy revealed an improvement in the social life of the majority of the patients, and there were cases of great improvement, with patients returning to work. ${ }^{23}$

In stereotactic bifrontal and subcaudate tractotomy procedures, it was noted that many patients remained unaltered or did not show any major improvements. ${ }^{19,49}$ A stereotactic limbic leucotomy appeared to have better results, with fewer patients remaining unchanged and cases displaying great postsurgical clinical improvement. ${ }^{21,22}$ Regarding an anterior capsulotomy, an improvement in the positive and negative symptoms of schizophrenia was evident, ${ }^{4}$ emphasizing the importance of the capsule as a target. I the only case of hypothalamotomy analyzed, the authors reported that the patient had a rapid improvement in aggressiveness and resumed social interactions, ${ }^{13}$ but this was to be expected, as the hypothalamus is considered to be associated with aggressive behavior. ${ }^{14}$

It is important to note that, despite the improvement in the negative symptoms revealed in an anterior capsulotomy, there were improvements in the positive symptoms in all studies. Thus, the exploration of new targets based on the neurocircuitry involving schizophrenia, as well as the use of multiple targets, should be addressed, seeking to cover the full spectrum of symptoms, such as those involving the NAcc, the GP, and the VTA.

Leiphart and Valone ${ }^{53}$, seeking to compare several targets in their study, concluded that better results were reported among patients who underwent cingulotomy, followed by frontal leucotomy with cingulotomy, anterior callosotomy, frontal leucotomy, and subcaudate tractotomy.

However, it is observed that the parameters used to measure improvement in the results are different among the studies. Some, for example, used the CGI rating scales, while others used only the findings of patients and family members themselves, which generates biases. Therefore, such data cannot be considered sufficient to assert that one target is better than the other in its results. That said, it is important to establish a common parameter to evaluate operated schizophrenic patients in all scientific studies.

Within the range of the studies analyzed, it was noted that there are few ablative surgeries performed in patients with schizophrenia, which could be an effect of the fear of failure in a field that has not yet been explored, or because the procedures are performed, but not published due to their experimental character.

One of the important limitations found in the present study was the retrospective characteristic of some of the studies and their conduction many years after surgery, so many variables can influence the outcome during the post- operative period. In addition, studies addressing mental disorders in general, without adequate presurgical data, and without concern for the specificities of schizophrenia, are difficult to analyze in terms of the actual efficacy and safety of the procedures in this specific psychiatric disease.

\section{Conclusion}

Schizophrenia is a chronic and debilitating disease, which leads to the loss of quality of life and the compromise of daily activities. We conclude that the most common targets in surgical procedures are the PFC and cingulate gyrus, which emphasizes the need for more studies addressing the anterior capsule and the hypothalamus, since they have already revealed potential results.

Ablative surgeries are effective in improving the positive symptoms of the disease. However, the negative and cognitive symptoms still represent a challenge in the treatment of schizophrenia, indicating that more targets in neurosurgery should be explored, and that multiple targets should be addressed, such as the NAcc, the GP, and the VTA.

As for DBS, some studies have demonstrated hypothetical beneficial results, stimulating more scientific production about this promising approach. It is important to emphasize that the surgical approach to treat schizophrenic patients is still experimental, and more clinical trials are necessary, using common evaluation parameters in order to recommend its clinical application.

\section{Conflict of Interests}

The authors have no conflict of interests to declare.

\section{References}

1 Agarwal P, Sarris CE, Herschman Y, Agarwal N, Mammis A. Schizophrenia and neurosurgery: A dark past with hope of a brighter future. J Clin Neurosci 2016;34:53-58

2 Perez SM, Lodge DJ. New approaches to the management of schizophrenia: focus on aberrant hippocampal drive of dopamine pathways. Drug Des Devel Ther 2014;8:887-896

3 Gault JM, Davis R, Cascella NG, et al. Approaches to neuromodulation for schizophrenia. J Neurol Neurosurg Psychiatry 2018;89 (07):777-787

4 Liu W, Hao Q, Zhan S, et al. Long-term follow-up of mri-guided bilateral anterior capsulotomy in patients with refractory schizophrenia. Stereotact Funct Neurosurg 2014;92(03):145-152

5 Lorr M, Jenkins RL, Holsopple JQ. Factors descriptive of chronic schizophrenics selected for the operation of prefrontal lobotomy. J Consult Psychol 1954;18(04):293-296

6 Kim JS, Shin KS, Jung WH, Kim SN, Kwon JS, Chung CK. Power spectral aspects of the default mode network in schizophrenia: an MEG study. BMC Neurosci 2014;15:104

7 Ewing SG, Winter C. The ventral portion of the CA1 region of the hippocampus and the prefrontal cortex as candidate regions for neuromodulation in schizophrenia. Med Hypotheses 2013;80(06): 827-832

8 Gillespie AL, Samanaite R, Mill J, Egerton A, MacCabe JH. Is treatment-resistant schizophrenia categorically distinct from treatment-responsive schizophrenia? a systematic review. BMC Psychiatry 2017;17(01):12

9 Moeller S, Kalkwarf N, Lücke C, et al. Achieving stable remission with maintenance electroconvulsive therapy in a patient with 
treatment-resistant schizophrenia: A case report. Medicine (Baltimore) 2017;96(48):e8813

10 Faria MA Jr. Violence, mental illness, and the brain - A brief history of psychosurgery: Part 2 - From the limbic system and cingulotomy to deep brain stimulation. Surg Neurol Int 2013;4:75-75

11 Mikell CB, Sinha S, Sheth SA. Neurosurgery for schizophrenia: an update on pathophysiology and a novel therapeutic target. J Neurosurg 2016;124(04):917-928

12 Mikell CB, McKhann GM, Segal S, McGovern RA, Wallenstein MB, Moore $\mathrm{H}$. The hippocampus and nucleus accumbens as potential therapeutic targets for neurosurgical intervention in schizophrenia. Stereotact Funct Neurosurg 2009;87(04):256-265

13 Schvarcz JR, Driollet R, Rios E, Betti O. Stereotactic hypothalamotomy for behaviour disorders. J Neurol Neurosurg Psychiatry 1972;35(03):356-359

14 Barbosa DAN, de Oliveira-Souza R, Monte Santo F, de Oliveira Faria AC, Gorgulho AA, De Salles AAF. The hypothalamus at the crossroads of psychopathology and neurosurgery. Neurosurg Focus 2017;43(03):E15-E15

15 Benson DF, Stuss DT, Naeser MA, Weir WS, Kaplan EF, Levine HL. The long-term effects of prefrontal leukotomy. Arch Neurol 1981; 38(03):165-169

16 Kelly D, Walter CJ, Mitchell-Heggs N, Sargant W. Modified leucotomy assessed clinically, physiologically and psychologically at six weeks and eighteen months. Br J Psychiatry 1972;120(554):19-29

17 McKenzie KG, Kaczanowski G. Prefrontal leucotomy: a five-year controlled study. Can Med Assoc J 1964;91:1193-1196

18 Hirose S. Orbito-ventromedial undercutting 1957-1963; Followup study of 77 cases. Am J Psychiatry 1965;121:1194-1202

19 Ström-Olsen R, Carlisle S. Bi-frontal stereotactic tractotomy. A follow-up study of its effects on 210 patients. Br J Psychiatry 1971; 118(543):141-154

20 Göktepe EO, Young LB, Bridges PK. A further review of the results of sterotactic subcaudate tractotomy. Br J Psychiatry 1975; 126:270-280

21 Kelly D, Richardson A, Mitchell-Heggs N, Greenup J, Chen C, Hafner RJ. Stereotactic limbic leucotomy: a preliminary report on forty patients. Br J Psychiatry 1973;123(573):141-148

22 Mitchell-Heggs N, Kelly D, Richardson A. Stereotactic limbic leucotomy-a follow-up at 16 months. Br J Psychiatry 1976; 128:226-240

23 Parhad MB. Bilateral cingulo-tractotomy. J Neurosurg 1953;10 (05):483-489

24 Ballantine HT Jr, Bouckoms AJ, Thomas EK, Giriunas IE. Treatment of psychiatric illness by stereotactic cingulotomy. Biol Psychiatry 1987;22(07):807-819

25 Corripio I, Sarró S, McKenna PJ, et al. Clinical improvement in a treatment-resistant patient with schizophrenia treated with deep brain stimulation. Biol Psychiatry 2016;80(08):e69-e70

26 Anderson CA, Arciniegas DB. Neurosurgical interventions for neuropsychiatric syndromes. Curr Psychiatry Rep 2004;6(05): 355-363

27 Hoffman JL. Clinical observations concerning schizophrenic patients treated by prefrontal leukotomy. N Engl J Med 1949; 241(06):233-236

28 Bartlett J, Bridges P, Kelly D. Contemporary indications for psychosurgery. Br J Psychiatry 1981;138:507-511

29 Stone JL. Dr. Gottlieb Burckhardt-the pioneer of psychosurgery. J Hist Neurosci 2001;10(01):79-92

30 Friedman S, Moore BE, Ranger CO, Russman C. A progress study of lobotomized and control patients. Am J Psychiatry 1951;108(01): $10-18$
31 Jenkins RL, Holsopple JQ Lorr M. Effects of prefrontal lobotomy on patients with severe chronic schizophrenia. Am J Psychiatry 1954;111(02):84-90

32 Freyhan FA. Prefrontal lobotomy and transorbital leucotomy: a comparative study of 175 patients. Am J Psychiatry 1954;111(01): 22-32

33 Hoch PH, Pool JL, Ransohoff J, Cattell JP, Pennes HH. The psychosurgical treatment of pseudoneurotic schizophrenia. Am J Psychiatry 1955;111(09):653-658

34 Lorr M, Holsopple JQ, Jenkins RL, O'Connor JP. Factors of change in lobotomized chronic schizophrenic patients. J Consult Psychol 1955;19(01):39-43

35 Hanlon TE, Sheets CS, Kurland AA. Spontaneous fluctuations in the severity of illness of hospitalized lobotomized patients. J Clin Psychol 1958;14(01):6-10

36 Smith A, Kinder EF. Changes in psychological test performances of brain-operated schizophrenics after 8 years. Science 1959;129 (3342):149-150

37 Hamlin RM, Kinder EF. Vocabulary deficit in brain operated schizophrenics. J Consult Psychol 1961;25:239-244

38 Oltman JE, Friedman S. Long-term results of frontal lobotomy in schizophrenic patients. Am J Psychiatry 1961;118:70-71

39 De Mille R. An incidental observation of epilepsy in catatonic schizophrenics after prefrontal lobotomy. J Nerv Ment Dis 1962; 134:182-183

40 De Mille R. Intellectual effects of transorbital versus prefrontal lobotomy in schizophrenia: a follow-up study. J Clin Psychol 1962;18:61-62

41 Sykes MK, Tredgold RF. Restricted orbital undercutting; a study of its effects on 350 patients over the ten years 1951-1960. Br J Psychiatry 1964;110:609-640

42 Hamlin RM. Intellectual function 14 years after frontal lobe surgery. Cortex 1970;6(03):299-307

43 Freeman W. Frontal lobotomy in early schizophrenia. Long follow-up in 415 cases. Br J Psychiatry 1971;119(553):621-624

44 Wehler R, Hoffmann H. Intellectual functioning in lobotomized and non-lobotomized long term chronic schizophrenic patients. J Clin Psychol 1978;34(02):449-451

45 Hussain ES, Freeman H, Jones RA. A cohort study of psychosurgery cases from a defined population. J Neurol Neurosurg Psychiatry 1988;51(03):345-352

46 Kucharski A. History of frontal lobotomy in the United States, 1935-1955. Neurosurgery 1984;14(06):765-772

47 Knight G. Stereotactic tractotomy in the surgical treatment of mental illness. J Neurol Neurosurg Psychiatry 1965;28: 304-310

48 Berstein IC, Callahan WA, Jaranson JM. Lobotomy in private practice. Arch Gen Psychiatry 1975;32(08):1041-1047

49 Nicolaidis S. Neurosurgery of the future: Deep brain stimulations and manipulations. Metabolism 2017;69S:S16-S20

50 Toga AW, Clark KA, Thompson PM, Shattuck DW, Van Horn JD. Mapping the human connectome. Neurosurgery 2012;71(01): $1-5$

51 Bourdillon P, Apra C, Lévêque M, Vinckier F. Neuroplasticity and the brain connectome: what can Jean Talairach's reflections bring to modern psychosurgery? Neurosurg Focus 2017;43(03): E11-E11

52 Gasquoine PG. Localization of function in anterior cingulate cortex: from psychosurgery to functional neuroimaging. Neurosci Biobehav Rev 2013;37(03):340-348

53 Leiphart JW, Valone FH III. Stereotactic lesions for the treatment of psychiatric disorders. J Neurosurg 2010;113(06):1204-1211 